\title{
Ethical issues and legal principles regarding joint management of shared river basins in the context of climate change and water scarcity in the Iberian Peninsula
}

\author{
Alexandra Aragão ${ }^{1}$ (D) \\ Received: 30 April 2021 / Revised: 6 July 2021 / Accepted: 14 July 2021 / Published online: 11 August 2021 \\ (c) The Author(s), under exclusive licence to Springer Nature Switzerland AG 2021
}

\begin{abstract}
Portugal and Spain share five large river basins. The human activities carried out in the rivers or in the river basin area generate mutual interferences and impacts on the quality and quantity of water and on the ecologic conditions of the rivers and surrounding ecosystems. Furthermore, the effects of climate change on river ecosystems in the Mediterranean region-namely drought, water scarcity, desertification, flooding, heat waves, soil salinization, invasive species-are leading to larger water stress periods and an overall reduction of ecosystem services. In this context, the main ethic challenges regarding joint management of shared river basins in the Iberian Peninsula are: territorial equity, geomorphologic equity, demographic equity, interspecies equity, development equity, intergenerational equity and cultural equity. To address these challenges, a set of principles of international environmental law are briefly analysed. These principles govern the relations between States, regulate the access to the rivers, preserve the ecologic equilibrium of the rivers, and influence risk management. The principles also limit State discretionarily towards possible river uses and shape international agreements to be adopted in the future.
\end{abstract}

Keywords Shared river basins $\cdot$ Iberian Peninsula $\cdot$ Ethic challenges $\cdot$ Equity goals $\cdot$ Legal principles

\section{Ethical issues regarding joint management of shared river basins in the context of climate change and water scarcity}

Climate change has altered profoundly the river dynamics, hydrology and flow regimes. Water scarcity does not allow the States to respect the duty of ensuring the minimal ecological flows (minimum quantity of water that should be left in the river even in times of draught). In transnational rivers, the international legal instruments in force became outdated and legal obligations regarding water quantity are frequently disregarded. Stakeholders ${ }^{1}$ and political powers ${ }^{2}$ insist upon the necessity of introducing amendments and

Alexandra Aragão

aaragao@fd.uc.pt

1 Institute for Legal Research, Faculty of Law University of Coimbra, Coimbra, Portugal renegotiating the Conventions on shared rivers. Is this revision a free decision of the signatories? Or on the contrary, is the contents of any future treaty or agreement conditioned by legal principles that restrain the freedom of the State parties? In the case of Portugal and Spain, the Albufeira Convention and the water framework directive and other international legal instruments set the scene for river basin management.

The purpose of the current article is to identify the ethical issues to be considered and the legal principles that establish limitations to the exercise of the discretionary powers of the Iberian States when renegotiating the Albufeira Convention currently in force.

Portugal and Spain share five large river basins: Minho/ Miño, Lima/Limia, Douro/Duero, Tejo/Tajo, Guadiana

\footnotetext{
1 See the position taken by the NGO "Zero" on the $23^{\text {rd }}$ of August 2018 (available at https://zero.ong/tejo-alerta-sobre-qualidade-daagua-reforca-necessidade-de-revisao-da-convencao-de-albufeira/).

2 Resolutions n. 28/2020 of the Portuguese Parliament, adopted on the 16th of June 2020, recommending the government to amend the Albufeira Convention for the defence of the Tagus river and of the international riverbasins (available at https://dre.pt/home/-/dre/13584 4792/details/maximized).
} 
Fig. 1 Aspect of the shared rivers and river basins, available at https://www.un.org/waterforli fedecade/water_cooperation 2013/albufeira_convention. shtml

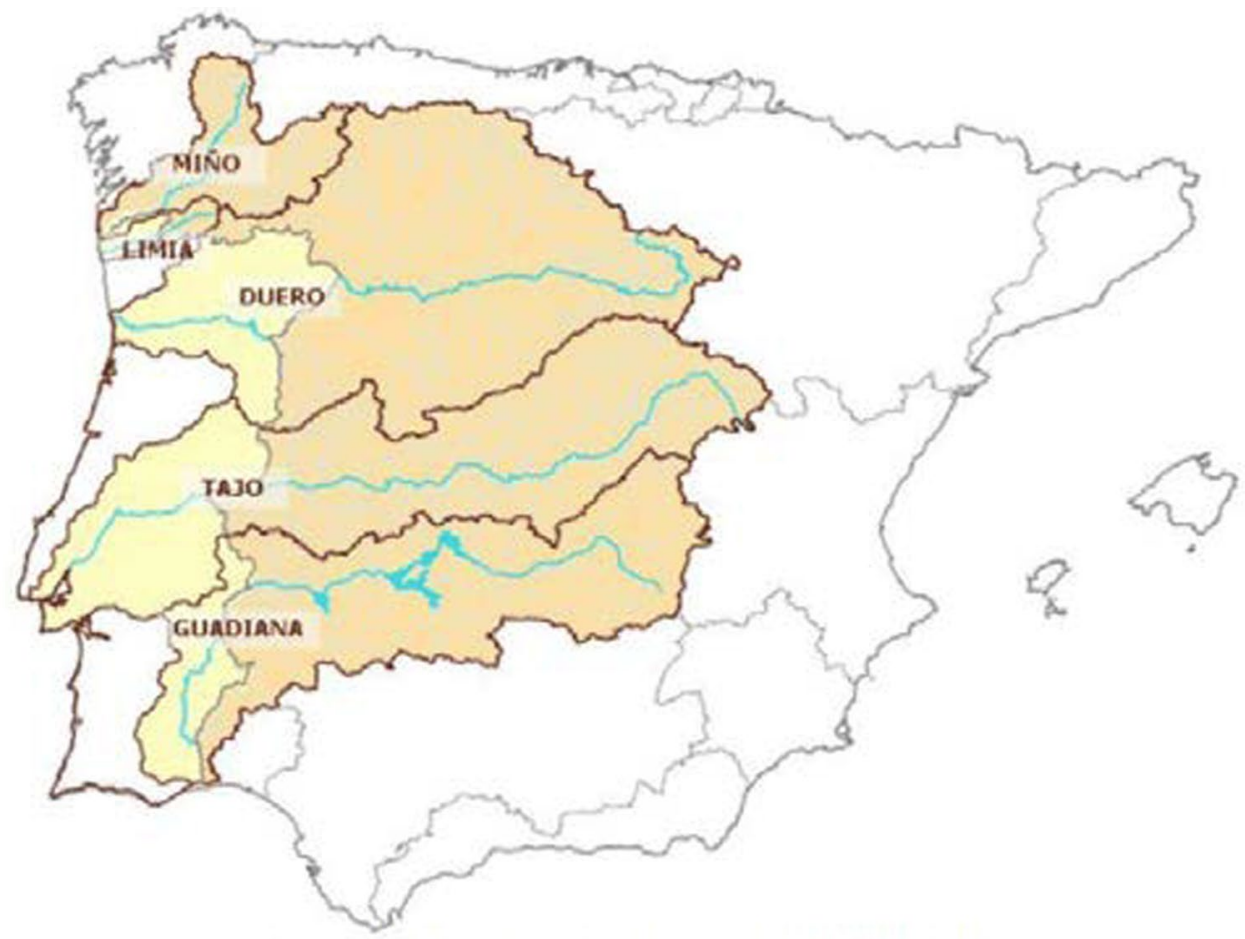

Main river basins shared between Spain and Portugal.

Source: Commission for the implementation and development of the Albufeira Convention.
(Fig. 1). In both national laws, rivers are regarded as public domain goods or, in other words, natural goods belonging to the State or other public entities. ${ }^{3}$ However, there are mutual interferences caused by human activities on both sides of the rivers that affect the quality and quantity of water in the water courses and the ecologic conditions of the rivers and surrounding ecosystems in the Portuguese and Spanish side of the river basin. Bridges, hydroelectric dams, sand extraction, water abstraction or fisheries, have a direct influence on the rivers. But the main difficulty of river basin management comes from the fact that other apparently innocuous landscape transformation activities, carried out far away from the watercourses contribute as well to the deterioration of the river and groundwater conditions. There are many examples of activities that, in the long run, can

\footnotetext{
${ }^{3}$ For Portugal see article 5 of the Constitution (available at https:// dre.pt/constitution-of-the-portuguese-republic) and the law establishing the titularity of water resources. According to the Law 54/2005, of the 15th November amended in 2013, 2014 and 2016, the public water domain can belong to the State, the autonomous regions, the municipalities and the parishes. (Article $2 \mathrm{n} .2$ ans article 6 available at http://www.pgdlisboa.pt/leis/lei_mostra_articulado.php?nid= $1377 \&$ tabela $=$ leis).

For Spain see the article 132 of the Constitution (available at https:// app.congreso.es/consti/constitucion/indice/imprimir/sinopsis_pr. jsp?art=132\&tipo=2) and article 339 of the Civil Code (available at https://noticias.juridicas.com/base_datos/Privado/cc.12t1.html).
}

change the ecological conditions of superficial and groundwater masses ${ }^{4}$ : slope deforestation causes soil erosion and silting up river beds; mining leachate runoff causes chemical contamination of water; intensive use of fertilizers in agriculture causes eutrophication; bad landfill management can cause contamination with microplastics; road construction and other soil sealing activities reduce the levels of the aquifers and lead to loss of habitats; atmospheric pollutant emissions from motorized traffic and housing, induce water acidification; and industrial accidents can lead to soil and water contamination.

Besides, differences in economic development, differences in demographic density on each side of the river basin lead to dissimilar impacts on river ecosystems (Fonseca et al. 2020) and potential legal conflicts.

To make things worse, climate change is the final disrupting factor with a potential to increase social disturbance related to water uses (European Commission 2009a, b). The effects of climate change on river ecosystems in the Mediterranean region-drought, water scarcity, desertification, flooding, heat waves, soil salinization, invasive

\footnotetext{
4 The Draft articles on the Law of Transboundary Aquifers adopted by the International Law Commission in 2008, and submitted to the General Assembly define "recharge zone" as "the zone which contributes water to an aquifer, consisting of the catchment area of rainfall water and the area where such water flows to an aquifer by runoff on the ground and infiltration through soil" (article $2 \mathrm{~g}$ ) (https://legal. un.org/ilc/texts/instruments/english/draft_articles/8_5_2008.pdf).
} 
species-lead to larger water stress periods and to an overall reduction of ecosystem services (Do and Seiz 2021). As consequence, wellbeing of communities dependent on river ecosystems is reduced as well.

Furthermore, the rivers are not static natural entities. The flowing waters running to the sea and the moving fish swimming across the stream are the most emblematic and useful elements of the river ecosystem are very dynamic. Consequently, the regulation of possible uses of a dynamic resource, must be flexible enough to accommodate variations of water quantity and quality, river shape and other features (Ojeda et al. 2006; Grases et al. 2020).

The analysis of the complexity of transnational river basin management in the context of climate change and associated water scarcity, brings to the spot light major ethic challenges on water governance (Groenfeldt and Schmidt 2013; Marone and Bohle 2020). These challenges fall within the scope of geoethics, an area of research that deals with "values which underpin appropriate behaviours and practices, wherever human activities interact with the Earth system" (Di Capua et al. 2021). Differently from other publications on geoethics, the current text does not address mainly the responsibilities of geoscientists (Peppoloni et al. 2019), such as hydrologists or geologists, but rather the responsibility of public authorities when they act as decision makers, authorising, conditioning or supervising the operators of economic activities which use water bodies or which benefit from water services.

The major ethic challenges and corresponding equity goals regarding joint management of shared river basins will deliberately be presented in a simplified manner for purposes of providing a big picture of the complexity of the bilateral peninsular controversies that are intensified by climate change.

1. regarding fair and balanced access to the river, a shared natural resource providing benefits for the riverside populations (Newson 1997). In contiguous rivers, that define the boundary line between two countries, as in the Guadiana river, sensitive issues of delimitation of the lowest line of a water course can emerge when the activities (like sand extraction) carried out on one side are likely to change the thalweg of the river.

2. (O) Territorial issues (cross sectional): ethical issues associated with the placement of the States in the course of the river flow (Falkenmark and Folke 2002). In successive rivers, the ethic challenges of preserving peaceful relations among neighbouring countries sharing water resources is the inequality of the relations between upstream and downstream countries due to the de facto power of the upriver country and the correspondent vul- nerability of the downriver country, as in the rivers Tejo/ Tajo or Douro/Duero.

3. on how easy the physical access to rivers is in each country (Gregory et al. 2008). The landscape features on each river bank (for instance, with flood plains on one side and steep slopes and rocky cliffs on the other) can make it more prone to access the river resources on one of the sides. Beyond the geophysical features, the existing infrastructure can also make a difference.

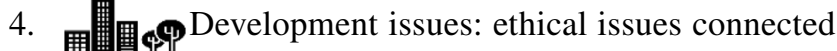
to the level of economic development of riverine regions (Hooper 2005). Water-intensive industries or mechanized farming in one of the river margins can induce overexploitation of river capacity. ${ }^{5}$ Strong technological capacity to exploit the river resources and to use the river "services" on one of the river banks engenders further inequalities. 5. $\therefore 0$ Demographic issues: ethical issues correlate to diverse demographic dispersion on each riverside can as well lead to inequities (Jager et al. 2016). Population density can originate quite different levels of appropriation on both States (for instance more water abduction, waste water emissions, fisheries, fish farms, etc.)

6. Cultural issues: ethical issues determined by the strength of the bonds between human communities and rivers (Jackson 2010). The geomorphologic, socioeconomic and demographic dissimilarities are sharpened when the cultural differences lead to peculiar community practices associated with rivers collective symbols or identity markers. Unique visions and feelings towards the rivers accentuate the perceived unfairness of foreign uses, triggering social conflicts and potential legal disputes (Argyrou and Hummels 2019).

7. 1 Interspecies issues: ethical issues regarding coexistence of humans and non-human species, dependent on river ecosystems in the same space and time (Whyte and Cuomo 2016). Most of the human activities likely to have impact on the rivers can trigger direct or indirect

\footnotetext{
5 The case, judged by the International Court of Justice in 2010, concerning the Uruguay river between Argentina and Uruguay, is the best example of a border conflict arising from water uses for industrial activities (paper pulp production) on one side (Uruguay), causing environmental impacts on the other (Argentina) (available at https:// www.icj-cij.org/public/files/case-related/135/135-20100420-JUD-0100-EN.pdf).
} 
conflicts with species even if they are inedible or are not even known to human beings (Watters 1996). ${ }^{6}$

8. resource conservation and environmental quality of the natural resources that will be left for future generations (Fedra 2015). Some activities that are necessary to allow the realization of all the potential uses of the rivers have irreversible impacts. Dams for hydropower production, for instance, cause huge and hardly reversible impacts in the area of the dam reservoir (Opperman et al. 2021; European Commission 2018).

The fact that the economic, social and cultural dependency on the river of communities on both sides can be quite different, is the reason why it is so important to develop legal regimes to regulate human activities on watercourses and to establish limitations to water uses and soil mobilization which may cause harm or loss of benefits (Schafer 2021) to the neighbouring country. ${ }^{7}$

The current context of climate change has made international cooperation in river management harder. The international agreements in force, were signed before the formal adoption of climate change laws and brings the issue of treaty renegotiation to the political foreground.

States can terminate contracts, suspend diplomatic relations, quit bilateral agreements, withdraw from bodies of international organizations, but they will still be tied by the shared environmental asset and can neither detach from the inescapable factual relation nor give up the interaction that comes from using a common river basin.

Despite the policy discretion inherent to any international negotiation, there are limits to the free will of the parties: be it European obligations deriving from applicable directives, be it legal principles enshrined in international conventions supporting international practice.

Even if for purposes of analysis we separate European Union law from International Law, the interactions between both levels of legislation are strong (Tignino 2014).

\footnotetext{
${ }^{6}$ In 2010, the project for one large dam in the north of Portugal (Padroselos dam, in Beça river) had a negative environmental impact assessment because of a small non-edible mussel. The monitoring report for three rivers shows the evolution of the Bivalvia (Biosfera (2017) Relatório de monitorização dos mexilhões-de-rio available at https://siaia.apambiente.pt/AIADOC/PA402/mexilh\%C3\%B5es2 02078155454.pdf).

7 The Lake Lanoux case opposed Spain to France on the regulation of common waters regarding the utilization of the hydraulic force of international watercourses by the upstream State (France) eventually causing harm to the interests of the downstream country (Spain). The case was decided in 1957 by an arbitral court and the decision was favourable to France (http://www.fao.org/3/w9549e/w9549e07.htm\# bm07.2.7).
}

\section{Obligations stemming from the EU water framework directive}

The European water framework directive applies both to national and international rivers and respective river basins. Regarding international watercourses, the European norms are applicable both to transboundary water courses shared among European Member States and to water courses shared with non-EU States. The legal strength of MS obligations different in each case.

For intra-European transboundary water courses, Member States shall coordinate their efforts for the achievement of the environmental objectives established under the water framework directive, and in particular all programmes of measures for the whole of the river basin district (preamble, paragraph $35^{8}$ ).

For river basins extending beyond the boundaries of the European Union, Member States should endeavour to ensure the appropriate coordination with the relevant non-Member States. Of course, this commitment to coordinate transboundary water courses that are only "partialy non-european" depends on the good will and willingness to cooperate of non-EU States.

There are examples inside and outside the European continent. It is the case of the Danube river mouth, between Romenia and Ucrania, or the Oiapoque river basin, between the French Guiana and Brasil. In both cases, the EU Member States (Romenia and France) shall "endeavour" to organise a proper coordination of river basin management with Ucrania and Brasil.

On the contrary, in the case of the intra-European river basins, such as the Iberian transboundary water courses, a strict duty of coordination applies.

This coordination means that first, the Member States have to put in place a legislative framework that allows the prosecution of the objectives established in the water framework directive.

Second, they have to set up an administrative river basin management structure that oversees water management, supervises water uses and ensures a good water status.

\footnotetext{
${ }^{8}$ Preamble (35) Within a river basin where use of water may have transboundary effects, the requirements for the achievement of the environmental objectives established under this Directive, and in particular all programmes of measures, should be coordinated for the whole of the river basin district. For river basins extending beyond the boundaries of the Community, Member States should endeavour to ensure the appropriate coordination with the relevant non-Member States. This Directive is to contribute to the implementation of Community obligations under international conventions on water protection and management, notably the United Nations Convention on the protection and use of transboundary water courses and international lakes, approved by Council Decision 95/308/EC and any succeeding agreements on its application.
} 


\subsection{Legislative framework for national catchment area of transboundary river-basins}

The requirements of the legal framework stem from the Preamble $(\S 18)$ of the water framework directive, which states that "Community water policy requires a transparent, effective and coherent legislative framework".

To begin, the common objectives shall be pursued with transparency. The public, in both sides of the river basin, has the right of access to information on the status of water, species, ecosystems, impacting activities, environmental risks, accidents, and also about legal, administrative and judicial measures to be taken to address these issues.

Next, the legal system implemented must be effective. In other words, the final goal of the legal framework is delivering "good quality surface water and groundwater as needed for sustainable, balanced and equitable water use" (article $1 \mathrm{e})$.

Effectiveness can be measured using environmental, social or legal indicators to assess the degree in which the desired legal results are attained.

Most important of all, coherence: the existence of a directive determining the goals to be achieved and the time frames to achieve them, is a guarantee in itself that the national legislative frameworks of the MS will somehow be coherent. Of course, the directive leaves the Member states some freedom of choice on the means to pursue the objectives but the goals are established at the EU level.

Several tests can be performed to assess whether the legislation complies with the obligation of being coherent: are there similar legal requirements for activities being carried out in both sides of the river basin area? Are protected areas near the border complemented by similar protections across the border? Alternatively, are there buffer zones near the border? Are protected species (beyond Natura 2000) coincident?

If the answer is yes, then the legal framework is coherent.

\subsection{Administrative coordination in transboundary river basin management}

The administrative coordination of intra-European transboundary water courses management must be effective.

The effectiveness of river basin management depends on the existence of quantity and quality control of water, prevention of transboundary water problems, protection of ecosystems, (aquatic, terrestrial and wetlands), safeguard of potential use of water, design of surveillance monitoring programmes, sustainable uses of water.

These requirements are confirmed by the Preamble (\$23) of the water framework directive: "Common principles are needed to coordinate Member States' efforts to improve the protection of Community waters in terms of quantity and quality, to promote sustainable water use, to contribute to the control of transboundary water problems, to protect aquatic ecosystems, and terrestrial ecosystems and wetlands directly depending on them, and to safeguard and develop the potential uses of Community waters".

In the water framework directive, the effectiveness of design is mentioned in annex $\mathrm{V}$ on surveillance monitoring programmes: "1.3.1. Member States shall establish surveillance monitoring programmes to provide information for: (...) the efficient and effective design of future monitoring programmes".

Besides, the appropriate way to ensure effective management, according to the EU, is identifying the appropriate competent authority. However, the EU does not go further in defining the nature of the authority. It can be national or international. It can be an existing entity or a new entity designated in the context of an international agreement in force.

This is clearly stated in article 4 of the water framework directive: "for international river basin districts the Member States concerned shall together ensure this coordination and may, for this purpose, use existing structures stemming from international agreements" (n.4 in fine) and "Member States may identify an existing national or international body as competent authority for the purposes of this Directive" (n.6.).

Therefore, according to the Directive, there is no obligation to create joint management bodies. Effective coordination of pre-existing national or international entities is sufficient under the scope of the Directive.

Besides, the activity of the competent authorities must contribute for the adoption of a concrete programme of measures for the promotion of the sustainability of the river basin. Article 4 n.4 determines that "Member States shall ensure that the requirements of this Directive for the achievement of the environmental objectives established under Article 4, and in particular all programmes of measures are coordinated for the whole of the river basin district» (article $3 . n^{\circ} 4$ ).

More important of all, the Commission can act to facilitate the establishment of the programmes of measures at the request of the Member States involved in joint management of international river basin districts.

Besides adopting a programme of measures, the other substantive requirement is installing a surveillance monitoring programme as established in Annex V 2.4.2.: "transboundary water bodies shall also be monitored for those parameters which are relevant for the protection of all of the uses supported by the groundwater flow".

Monitoring is particularly important to ensure an effective and transparent management. 


\subsection{The final goal of coordination between Member States}

The purpose of coordination goes much beyond the mere fulfilling of a formal procedure, carried out for the sake of respecting the principle of common management of shared resources. The real reason behind the coordination effort is the recognition that the only way to achieve a good water status along the entire course of the river and a sustainable use of the water course is the conjunction of efforts for the attainment of the environmental objectives.

Article $3 \mathrm{n} .4$ of the water framework directive is clear: "Member States shall ensure that the requirements of this Directive for the achievement of the environmental objectives established under Article 4, and in particular all programmes of measures are coordinated for the whole of the river basin district."

The environmental objectives to be attained through international coordination are defined in article 4 of the water framework directive: "achieve good water status for surface water, groundwater and protected areas". This implies three approaches: preventing deterioration (no regression); reversing negative trends (long-term no regression), and protecting, enhancing and restoring good water status (progress).

These approaches will be addressed in the following section, on obligations steaming from international conventions.

\section{Obligations stemming from international conventions}

The analysis of international conventions will concentrate on the specific international agreement adopted for the Iberian Peninsula ${ }^{9}$ in 1997: the Albufeira Convention. There are two main purposes of the Albufeira Convention (article 2. n. $1^{10}$ ):

1. "the protection of surface and groundwater and the terrestrial and aquatic ecosystems directly dependent on them"

2. "the sustainable use of water resources in the hydrographic basins".

For the attainment of these purposes, the Albufeira Convention defines the framework of cooperation between the Parties.

It is true that the revision or the replacement of a bilateral convention in force-such as the Albufeira Conventiondepends, first of all, on the converging political will of the

\footnotetext{
${ }^{9}$ Excluding the microstate of the Principality of Andorra in the border between Spain and France.

10 The full text can be found here: https://snirh.apambiente.pt/index. php?idMain=6\&idItem $=1$ \&idISubtem $=$ revis622008.
}

States. This political will can correspond to a political programme or be the result of internal pressure ${ }^{11}$ or derive from international commitments. ${ }^{12}$

However, it is important to acknowledge that when two sovereign States decide to engage in negotiations for the revision or replacement of an international agreement, regulating mutual relations, they are neither totally free to depart from previous agreements.

The negotiations will be held in the context of broader normative aquis, which frames the negotiating power and circumscribe the liberty of the parties is shaping the contents of the future international agreement.

This is in accordance with the present version of the Albufeira Convention which clearly recognizes that "in pursuing this cooperation, the Parties comply with the rules of this Convention and the principles and rules of international and Community law applicable" (article 2 n.2).

This limited freedom is particularly evident in the case of environmental norms and sustainability norms insofar as environmental protection and sustainability guarantee seem to be the ultimate goal of the Albufeira Convention.

The most important environmental limits and constraints to the negotiation of an intergovernmental bilateral agreement on shared river basins between Portugal and Spain will be presented in the form of well-known legal principles, ${ }^{13}$ all of them existing in international normative instruments legally binding for Portugal and Spain.

\footnotetext{
11 The political parties represented in the Portuguese Parliament consider the revision of the Albufeira Convention on an urgent issue of national relevance. http://app.parlamento.pt/WebUtils/docs/doc.pdf? Path $=6148523063446 f 764 c 324679626 d 56304 \mathrm{c} 334 \mathrm{e} 706447567 \mathrm{a} 4 \mathrm{c}$ 31684a566b784652793944543030764d54464451555650564339426 36e463161585a765132397461584e7a5957387654334a6b5a57357a $4947526 \mathrm{c} 4946527959574 \mathrm{a} 68624768764 \mathrm{c} 304 \mathrm{e} 4252553955587 \mathrm{a} 466$ 64d5463756347526d\&Fich=CAEOT_1_17.pdf\&Inline=true.

Also, from the Spanish side, a decision from 11 March 2019 of the Supreme Court, could be of relevance. It annulled partially the Spanish hydrologic plan for the Tagus river, one of the reasons being the inadequate treatment of ecological down streams (STS 856/2019, http://www.poderjudicial.es/search/AN/openCDocument/47c54a4d73 e1a196f05b951244f113f6d1057617ced3c47d

12 The Implementation Review Report presented by the European Commission underlines some cases of non-compliance by the Member States which could be addressed and tackled in a revision of the existing agreements (European Commission 2019).

13 These environmental principles are addressed in several chapter of the volume VI of The Elgar Encyclopaedia of Environmental Law (Edward Elgar, 2018), the most overarching and updated piece of legal literature on "Principles of Environmental Law". Particularly important for the subject is the chapter on "Environmental principles in maritime and freshwater agreements", by Mariachiara Alberton (2018) (pp. 525-535).
} 


\section{Legal principles on shared river basins}

Environmental law is a branch of law that must evolve very rapidly to adapt to the new challenges posed by the fasttechnological progress ${ }^{14}$ and to correspond to the growing scientific knowledge on the factors causing river pollution (Rachid et al. 2015), degradation (Calay and Dhiman 2008) or loss of river flow connectivity (European Environmental Agency 2020). This is why environmental law is rich in legal principles performing different functions (legislative update via interpretation, integration of legislative gaps, judicial correction of administrative measures, etc.) (de Sadeleer 2002). Most importantly, the principles help the legal system to respond to the ethical concerns raised by the impact of anthropogenic activities. Some principles establish procedural obligations, such as the principle of access to information, public participation and access to justice. These principles, enshrined in the Aarhus Convention, ${ }^{15} \mathrm{EU}$ directives, ${ }^{16}$ regulations ${ }^{17}$ and communications, ${ }^{18}$ and national laws, are the pillars for the consolidation of environmental

\footnotetext{
$\overline{14}$ For instance, the so called "fish-safe" turbines and pass through systems for small-dam hydropower projects (Meister 2020).

15 The 1998 UNECE Convention on Access to Information, Public Participation in Decision-making and Access to Justice in Environmental Matters (Aarhus Convention) (available at https://unece.org/ environment-policy/public-participation/aarhus-convention/text).

16 Directive 2003/4/EC of the European Parliament and of the Council of 28 January 2003 on public access to environmental information (https://eur-lex.europa.eu/legal-content/EN/TXT/?uri=CELEX\% 3A32003L0004) and Directive 2003/35/EC of the European Parliament and of the Council of 26 May 2003 providing for public participation in respect of the drawing up of certain plans and programmes relating to the environment and amending with regard to public participation and access to justice Council Directives 85/337/EEC and 96/61/EC.

17 Regulation (EC) No 1367/2006 of the European Parliament and of the Council of 6 September 2006 on the application of the provisions of the Aarhus Convention on Access to Information, Public Participation in Decision-making and Access to Justice in Environmental Matters to Community institutions and bodies. In 2021 the Proposal for a new Regulation of the European Parliament and of the Council on the application of the provisions of the Aarhus Convention on Access to Information, Public Participation in Decision-making and Access to Justice in Environmental Matters to Community institutions and bodies is being discussed (on the basis of the Commission proposal COM(2020) 642 final 2020/0289 (COD) Brussels, 14.10.2020).

18 European Commission (2016) "Notice on Access to Justice in Environmental Matters", Communication from the Commission of 28.4.2017(C(2017) 2616 final, Brussels, 28.4.2017 (available at https://ec.europa.eu/environment/aarhus/pdf/notice_accesstojustice. pdf). European Commission (2020a, b) "Improving access to justice in environmental matters in the EU and its Member States", Сотmunication from the Commission to the European Parliament, the Council, the European Economic and Social Committee and the Committee of the Regions, (COM(2020) 643 final Brussels, 14.10.2020, available at https://ec.europa.eu/environment/aarhus/pdf/communication_impro ving_access_to_justice_environmental_matters.pdf).
}

democracy. Furthermore, according to the Almaty Guidelines on Promoting the Application of the Principles of the Aarhus Convention in International Forums, ${ }^{19}$ the inclusion of the democratic principles in any future Agreement to be negotiated, involving the parties of the Aarhus Convention, is mandatory.

Other principles establish substantive rights and shape substantive obligations of the States, of the providers of public services, of the economic operators and of the citizens.

\subsection{The relevance of a having a legal principles catalogue}

The international legal instruments in force, used for the environmental protection of rivers, were adopted more than 20 years ago. In the meantime, both the environmental context and the economic context have changed. Climate change and water scarcity made existing instruments obsolete and require new paradigms. The amount of water available to the downstream river communities is now shorter. Besides, the economic crisis after the covid-19 pandemic is a strong factor pushing the governments and administrations to authorize and accept new economic activities dependent on the rivers. From agriculture to energy, the risk of regression (Prieur and Sozzo 2012) in water law is real.

In this context, legal principles play the role of legal constraints to the prerogatives of the riparian States to use the river resources. Legal principles are fundamental to limit the rights of exploitation by the States, safeguarding the public interests associated with the rivers, to guarantee the sustainable use of riverine resources and to preserve the ecological equilibrium of the river ecosystems.

In the future, any negotiation of new international conventions regulating the rights and duties of the riparian States cannot ignore the system of principles that steams from already existing legal instruments.

Synthetically, principles play different roles (Schmeier 2021):

a. While the legal status quo is maintained, principles are relevant to reorient legal adjudication and enforcement procedures towards the more demanding needs imposed by climate change, as tools of international relations, diplomacy and judicial and non-judicial interactions between riparian states.

b. When the status quo is about to change, principles play a fundamental role in the negotiations of new international legal instruments, providing a framework for negotia-

\footnotetext{
19 The Almaty declaration is available at https://www.unece.org/filea dmin/DAM/env/documents/2005/pp/ece/ece.mp.pp.2005.2.add.5.e. pdf.
} 
tions on one hand, and being the object of negotiations on the other.

These principles will be presented in the form of a reasoned catalogue, a list organized following an internal logic oriented towards sustainable development. The catalogue of principles is much more than a simple list of random assumptions: the fact that they are organised and have an intrinsic rationale facilitates their consideration in future negotiations as a response to ethic challenges and equity goals. Their systematic organization simplifies their consideration by the negotiators of international agreements, by the legislative power, by the national administrations, and even by the courts.

\subsection{Methodology for the development of a catalogue of principles}

The methodology for identifying, selecting and organizing the relevant principles was a four-step process:

Step one, screening existing supranational or international legal sources of environmental law of general nature (such as the Stockholm, Rio and Rio + 20 declarations), of sectoral nature (such as the climate or biodiversity conventions) or specific to rivers and river basins (the UN conventions on watercourses and the Albufeira Convention applicable exclusively to the Iberian Peninsula (Portugal and Spain).

This screening resulted in a compilation of twelve legal instruments containing principles directly or indirectly applicable to river basin management: 1972 UN Stockholm declaration on human development; 1992 UN Convention on biologic diversity; 1992 UN Convention on Climate change; 1992 UN Convention on the protection and use of transboundary watercourses and international lakes (water Convention); 1992 UN General Assembly Resolution Rio declaration on environment and development (12 August) (A/CONF.151/26); 1997 Convention on non-navigational uses of international watercourses (UN watercourses Convention); 1998 Albufeira Convention on Cooperation for the Protection and Sustainable Use of Luso-Spanish Watershed Waters 2000 Charter of Fundamental Rights of the European Union; 2009 Treaty on the Functioning of the European Union Union; 2012 UN General Assembly Resolution The future we want (27 July) (A/RES/66/288); 2015 Paris Agreement on Climate Change; 2018 Escazu Regional Agreement on Access to Information, Public Participation and Justice in Environmental Matters in Latin America and the Caribbean.

Step two, scoping the international environmental instruments to find legal principles applicable both to human-river relations and to human-human relations in a river basin context. Ten principles were pinpointed. In alphabetic order, the principles considered fundamental for framing the rights and duties of the riparian states are: benefit sharing, common but differentiated responsibility, cooperative sovereign, correction at the source, high level of environmental protection, no regression and progress, prevention and precaution, sustainable development. The relevant norms enshrining these legal principles are organized in the Annex I.

Step three, finding intrinsic connections among principles. This research has revealed mutual affinities and, in the end, contributed for the construction of a system of principles. The criteria used for the establishment of logical associations among the principles are their scope and objectives. Considering the scope, some principles are more humancentred (principles on interstate relations) while others are more focused on the rivers as ecological entities (principles on ecologic equilibrium). Considering the objectives, some principles are more defensive, aimed at passively avoiding risks (principles on risk management), while others are more dynamic, aimed at proactively supporting sustainable management (principles on access to the rivers).

This step allows to organize the ten principles and present them associated in four groups:

a. Principles governing interstate relations: cooperative sovereignty and common but differentiated responsibility.

b. Principles regulating access to the rivers: sustainable development principle and benefit sharing.

c. Principles preserving the ecologic equilibrium of the rivers: high level of protection principle, no regression and progress principle.

d. Principles influencing risk management: prevention and precautionary principle and correction at the source.

Step four, is an exercise of recognizing and enunciating the major ethic challenges of international river basin management in a context of climate change and water scarcity. It is fundamental to convey the equity goals behind the legal principles. Finally, making a correspondence between the legal principles, the equity goals and the ethic challenges provides a crystal-clear understanding of the social and ecologic utility of the legal principles.

The following table is the result of the matching of eight ethic challenges, eight equity goals and ten legal principles, organized around four core themes. 


\begin{tabular}{|c|c|c|c|c|}
\hline & Ethic challenges & Equity goals & Core theme & Legal principle \\
\hline (reds & Territorial challenge & $\begin{array}{l}\text { Territorial equity } \\
\text { (longitudinal) }\end{array}$ & \multirow{2}{*}{$\begin{array}{l}\text { Principles } \\
\text { on } \\
\text { interstate } \\
\text { relations }\end{array}$} & cooperative sovereignty \\
\hline 요요 & Territorial challenge & $\begin{array}{l}\text { Territorial equity } \\
\text { (cross sectoral) }\end{array}$ & & $\begin{array}{l}\text { common but differentiated } \\
\text { responsibility }\end{array}$ \\
\hline 8 & $\begin{array}{l}\text { Geomorphologic } \\
\text { challenge }\end{array}$ & $\begin{array}{l}\text { Geomorphologic } \\
\text { equity }\end{array}$ & \multirow{2}{*}{$\begin{array}{l}\text { Principles } \\
\text { on access to } \\
\text { the rivers }\end{array}$} & benefit sharing \\
\hline 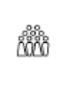 & Demographic challenge & $\begin{array}{l}\text { Demographic } \\
\text { equity }\end{array}$ & & sustainable development \\
\hline దిత్రి & Interspecies challenge & $\begin{array}{l}\text { Interspecies } \\
\text { equity }\end{array}$ & \multirow{2}{*}{$\begin{array}{l}\text { Principles } \\
\text { on ecologic } \\
\text { equilibrium }\end{array}$} & high level of protection \\
\hline Whese? & $\begin{array}{l}\text { Development } \\
\text { challenge }\end{array}$ & $\begin{array}{l}\text { Development } \\
\text { equity }\end{array}$ & & no regression and progress \\
\hline \multirow{2}{*}{ 1) } & $\begin{array}{l}\text { Intergenerational } \\
\text { challenge }\end{array}$ & $\begin{array}{c}\text { Intergenerational } \\
\text { equity }\end{array}$ & \multirow{2}{*}{$\begin{array}{c}\text { Principles } \\
\text { on risk } \\
\text { management }\end{array}$} & prevention and precaution \\
\hline & Cultural challenge & Cultural equity & & correction at the source \\
\hline
\end{tabular}

This methodology contributed for the construction of a catalogue of operational principles that frame any future treaty or convention on international river basin management.

\section{A catalogue of legal principles on shared river basins}

The full logic behind the matching of law and ethics, legal principles and equity goals, to produce a doctrinal catalogue of operational legal principles will be explained in detail in the following sections.

\subsection{Principles governing interstate relations: cooperative sovereignty and common but differentiated responsibility}

Considering that the object of the international agreement is an international river basin, the States must exercise their sovereignty over the resource in a cooperative way. Each State does not have an absolute sovereign right over its share of the resource. Even environmental impacts that are originated and mainly felt on the territory of one State can jeopardize the ecological equilibrium of all the river ecosystems. This is why they must cooperate to achieve the desired ecological equilibrium.

As a consequence, when negotiating the mutual obligations of the States with regard to the rivers, the States must cooperate in good faith considering the fact that no decision shall be taken by none of the States (including the downstream State) without consulting the authorities and the public in the other State.

Yet the States have different de facto powers regarding the river as a whole. In the case of successive rivers, considering the direction of the river flow, the upstream State has more factual power than the downstream State to modify and condition the ecological status of the river. Besides, in the proximity to the river mouth, biodiversity increases and therefore the downstream State is more conditioned in the economic activities to be authorised. In the case of contiguous rivers, the powers differ according to the percentage of the river basin area situated in the territory of each State.

As explained before, besides the geomorphologic differences, there can be also demographic variations (population density), socio-economic contrasts (more industrialised or more agricultural regions) or cultural diversity (social traditions and communities' attachment to the rivers), which must be considered in the definition of the concrete responsibilities and obligations of the States. 


\subsection{Principles regulating access to the rivers: sustainable development principle and benefit sharing}

The time and the space dimensions of sustainable development (Bosselmann 2016) must be present in the transboundary agreements. The first translates into intergenerational equity and the second reflects regional or local equity.

Regarding intergenerational equity, the States have sovereign rights over their natural resources, but they are only temporary holders of natural resources. The natural heritage must be passed on to the future generations. Each generation must leave the territory in the same (or possibly better) condition than it received it. This means that each generation can use the natural resources provided that it preserves, for the succeeding generations, similar environmental conditions, ensuring the future generations equitable access to environmental benefits. For nonrenewable resources, like rocks, minerals or fossil fuels, this may imply halting extractive uses and finding alternative sources of materials, in line with the new circular economy guidelines, or obtaining energy from renewable sources.

Therefore, when drafting the legal regime of water uses, the interests of future generations must be taken into account by considering the long-term effects of present decisions on activities that cause environmental effects such as soil sealing (urban or road construction) or biodiversity loss (deforestation). These activities mean less water availability in the future.

In what concerns intra generational equity: in the relations between the different populations coexisting in the same territory at the same time equity must as well be respected, both in the relations between countries and in the relations between national governments and local communities. This means that long distance effects must also be observed in any public policy likely to have direct or indirect effects on water. The interests of downstream communities must be accounted for when they are affected by telecoupling effects ${ }^{20}$ of excessive water abstraction upstream or contamination of a tributary by intensive agriculture or livestock farming.

In the case of relations between bordering States, equity is translated into benefit sharing. States are not allowed to use shared resources disproportionately, jeopardizing the rights of other States, regions or communities to have equitable access to the natural resources. In more simple words, the fact that the water appears in the springs in the Spanish mountains does not mean that States can freely collect

\footnotetext{
${ }^{20}$ According to Hull, V. and Liu, J. telecoupling refers to socioeconomic and environmental interactions between distant coupled human and natural systems, and has become more extensive and intensive in the globalized era (Hull and Liu 2018; Liu et al. 2019).
}

water for their urban, tourism, agriculture, farming, energy or industrial uses without entering into a dialogue with Portugal. The fact that in Portugal the water flows directly to the Atlantic Ocean does not mean that Portuguese water authorities can freely authorize the abstraction of water for swimming pools, water parks, irrigation, or industrial cooling, without considering the needs and the interests of local populations and the equilibrium of the river as a whole.

Due consideration of the interests, both of future generations and of local fluvial communities, requires carrying out thorough scientific studies, monitoring and reports on long term and long-range impacts.

\subsection{Principles preserving the ecologic equilibrium of the rivers: high level of protection, no regression and progress principle}

As explained before, the main purposes of the Albufeira Convention on are essentially environmental: "the protection surface and groundwater and aquatic and terrestrial ecosystems directly dependent on them" and "the sustainable use of water resources in the hydrographic basins". ${ }^{21}$

The objective of the agreement is to go beyond minimal environmental protection ensuring a high level of environmental protection (Jans et al. 2009). Minimal protection consists in respecting national water laws on both sides, based on the assumption that what is legal for one State must be acceptable to the other. Yet, this is not always the case. Long ago, the Trail Smelter case ${ }^{22}$ has shown that a legal industrial activity can nevertheless cause inadmissible damage when the industry is too close to the external boundaries of the neighbouring State. In this case, additional rules may be necessary to ensure fair international relations with neighbouring countries.

As a consequence, any revision, update or amendment of the Albufeira Convention on shall not downgrade, reduce or abolish the level of environmental protection established. Why? Because the purpose of the agreement is not to satisfy human needs. It is rather to protect the ecosystems and ecosystem services. However, we know that the environmental conditions are changing. Less biodiversity, climate disruption and reduction of water quantity and quality are the visible manifestations of environmental change.

\footnotetext{
21 Article $2 \mathrm{n} .1$ of the Albufeira Convention.

${ }^{22}$ In the beginning of the XX century Canada and the United States were involved in an international conflict over trans-boundary air pollution cased by an industrial facility located in Canada, but near the US border. The conflict was solved through arbitration in 1941 and contributed for the establishment of the no harm principle: activities carried out on the national territory must not cause transboundary pollution and harm in the neighbouring state (the case is available https://legal.un.org/riaa/cases/vol_III/1905-1982.pdf).
} 
The most obvious case where the "no regression" principle is fundamental is the maintenance of the ecological flows (European Commission 2015) prescribed in the Albufeira Convention. In view of the drought years that are more frequent each year and are expected to become even more in the next decades, ${ }^{23}$ it is now harder to respect the ecological flows. As a consequence, to prevent regression, human activities that depend heavily on water (tourism, agriculture, industry, mining) and whose maintenance imposes negative impacts on the rivers in periods of drought, should be stopped or at least suspended. Yet, many of these activities are fundamental to create jobs, promote the development of the country and sustain the quality of life.

But the Member States of the European Union are obliged to maintain "a high level of environmental protection and the improvement of the quality of the environment" (article 37 of the Charter of Fundamental Rights of the European Union). How can this be done? The non-regression principle requires that the States make all the efforts necessary to respect the environmental conditions of the rivers. Restoration of river ecosystem services (Feio et al. 2021) requires time, knowledge and investment, but is the only solution when the minimal ecological conditions required by the water framework directive cannot be met. Alternatively, in the meantime, the national authorities can consider other possibilities, such as replacing the activities that generate negative impacts on the rivers with lower impact activities, ensuring a more sustainable production. For instance, in agriculture, instead of intensive irrigation, there can be a change in the agricultural practises and agricultural products to less water demanding cultures (almond or olive trees, instead of avocado trees). In tourism, instead of filling the swimming pools with freshwater, use sea water whenever possible.

In conclusion, to ensure a high level of environmental protection the neighbouring States must, first of all, map every human activity likely to cause too much impact on the ecological state of the rivers. Consequently, they must suspend or replace these activities with others having less impact whenever possible. They must also map and assess the ecosystem services that are being lost and which require ecological restoration (European Commission 2020a, b). After assessing the restoration needs, the States will have to invest in reforestation, in replanting riverbank vegetation, in reintroduction of lost species, in replacement of soil sealed areas with permeable soil, in cleaning up contaminated sites, in creating more efficient wastewater treatment facilities, or even in dredging and cleaning the riverbeds. This is

\footnotetext{
$\overline{23}$ Considering the average for the period $1971-2000$, Portugal is suffering from longer and more frequent drought seasons (See the report on the state of the environment, Relatório do estado do ambiente 2019 (available at https://rea.apambiente.pt/content/seca).
}

not expenditure. It is investment, that hopefully will have a return in the medium or long term.

\subsection{Principles influencing risk management: prevention and precautionary principle and correction at the source}

Respect for the prevention and the precaution principles depends, first of all, on careful compliance with the EU Law on previous impact assessment and systematic participation of the public in the licencing procedures. For activities not submitted to EIA or SEA but likely to have some impact in the river or in the river basin, careful monitoring and attentive supervision of legal ongoing activities, along with smart detection of illegal activities, namely using spatial and digital technologies for earth observation and remote sensing, are indispensable. Prevention and precaution impose the States the obligation to proactively avoid every predictable environmental impact of human activities. As a consequence, activities carried out in the territory of a State shall respect due diligence obligations, to prevent any harm in the territory of another State (Salman and Salman 2021). In other words, this means that pollution and environmental degradation must be corrected at the source to prevent major environmental impacts. Minimal environmental impacts can be tolerated whenever environmental damage cannot be prevented, provided that there are no other cumulative or long-term impacts, that potential victims are informed and compensated and finally, that the ecological equilibrium is not at stake.

There are innumerable examples of activities covered by the precaution and the precautionary principles. Activities such as building and operating large dams, hazardous industrial activities involving dangerous substances or radiation located in the riverbanks, mining activities that use dangerous chemical substances or fisheries management activities, consisting on the introduction of new fish species with a high predator potential, are just some examples. The legality of these activities depends on specific procedures for assessing and balancing the known and unknown risks and on the proposal of adequate measures to prevent disasters from occurring.

The precautionary principle indicates that the States shall not carry out hazardous activities such as those mentioned, whenever they entail an important risk of severe environmental damage. If there are doubts on the risks or effects associated with human activities, precautionary measures shall be taken. Precautionary measures are provisional measures adopted to avoid negative effects "even if this 
risk cannot be fully demonstrated or quantified or its effects determined because of the insufficiency or inclusive nature of the scientific data". ${ }^{24}$ These measures must always be temporary and revised regularly. Besides, the strength of the measure must be proportionate to the probability, magnitude, seriousness and reversibility of the risk. Activities likely to generate catastrophic impacts must be forbidden for precautionary reasons. Activities that may eventually cause serious but reversible damage in a geographically limited area, should be submitted to precautionary monitoring. In any case, another consequence of the precautionary principle is the duty to produce scientific data, information and knowledge on the risk to dissipate the uncertainties that lead to the adoption of precautionary measures.

\section{Conclusion}

The ethic challenges of managing shared rivers in the context of climate change and water scarcity are the result of different types of unbalanced fluvial relations:

- between humans and the territory,

- humans among themselves (individual, community, institutional relations) and

- between humans and other species,

- between present and future generations (of humans and other species).

These challenges reflect trends of unfair practices of over exploitation, abuse of power, unequal use, and selfish appropriation.

The evolution of river dynamics under the pressure of climate change is inducing water scarcity. This new context explains the need for a legal revision of the existing instruments regulating transnational river basins. In the current situation of economic crisis, the risk of legal regression during the revision of international environmental agreements must be prevented.

In the European context, the water framework directive establishes obligations that limit Member States' discretionary power regarding shared river basin management.

Internationally, other broader legal instruments aimed at environmental protection, enshrine legal principles that can be used to refrain the total freedom to use and exploit the rivers.

The principles, organized according to logical criteria, set up a catalogue of operational sustainability principles.

\footnotetext{
${ }^{24}$ Communication from the Commission on the precautionary principle, $\operatorname{COM(2000)} 1$ final Brussels, 2.2.2000,page 13 (https://eur-lex. europa.eu/legal-content/EN/TXT/?uri=celex\%3A52000DC0001).
}

Having a catalogue is a powerful tool to inspire, guide and circumscribe discretionary powers, most of all when reviewing the legal regimes presently in force. In the short term, the catalogue can influence as well the application, implementation and enforcement of the current bilateral convention, because is responds to ethic challenges and contributes to the attainment of equity goals in the new context of climate change and water scarcity. In the long run, the application of the principles delivers sustainability.

Legal principles, existing in international law and practice, can be incorporated in new project authorizations, bilateral agreements, plans, programmes or laws relating to the rivers. They can be applied by governments, by administrative authorities or, if necessary, by the courts, to revert the unsustainable trends and lead to equity in the human-human and human-nature relations across international rivers (Fig. 1).

\section{Annex: the main legal sources of the principles}

Main legal sources for the mentioned principles in international law will be presented chronologically and without further analyses.

1. Cooperative sovereignty and common but differentiated responsibility in interstate relations

- 1972 UN Stockholm declaration on human development $^{25}$

"Principle 24 International matters concerning the protection and improvement of the environment should be handled in a cooperative spirit by all countries, big and small, on an equal footing.

Cooperation through multilateral or bilateral arrangements or other appropriate means is essential to effectively control, prevent, reduce and eliminate adverse environmental effects resulting from activities conducted in all spheres, in such a way that due account is taken of the sovereignty and interests of all States".

- 1992 UN General Assembly Resolution Rio declaration on environment and development (12 August) (A/ CONF.151/26) $)^{26}$

\footnotetext{
${ }_{25}$ Available at https://www.soas.ac.uk/cedep-demos/000_P514_IEL_ K3736-Demo/treaties/media/1972\%20Stockholm\%201972\%20-\% 20Declaration $\% 20$ of $\% 20$ the $\% 20$ United $\% 20$ Nations $\% 20$ Conference $\%$ 20on\%20the\%20Human\%20Environment\%20-\%20UNEP.pdf.

26 Available at https://www.un.org/en/development/desa/population/ migration/generalassembly/docs/globalcompact/A_CONF.151_26_ Vol.I_Declaration.pdf.
} 
"Principle 7 States shall cooperate in a spirit of global partnership to conserve, protect and restore the health and integrity of the Earth's ecosystem. In view of the different contributions to global environmental degradation, States have common but differentiated responsibilities. The developed countries acknowledge the responsibility that they bear in the international pursuit of sustainable development in view of the pressures their societies place on the global environment and of the technologies and financial resources they command".

- 1992 UN Convention on the protection and use of transboundary watercourses and international lakes (water Convention $)^{27}$

"Article 9 Bilateral and multilateral cooperation

1. The Riparian Parties shall on the basis of equality and reciprocity enter into bilateral or multilateral agreements or other arrangements, where these do not yet exist, or adapt existing ones, where necessary to eliminate the contradictions with the basic principles of this Convention, to define their mutual relations and conduct regarding the prevention, control and reduction of transboundary impact. The Riparian Parties shall specify the catchment area, or part(s) thereof, subject to cooperation. These agreements or arrangements shall embrace relevant issues covered by this Convention, as well as any other issues on which the Riparian Parties may deem it necessary to cooperate.

2. The agreements or arrangements mentioned in paragraph 1 of this article shall provide for the establishment of joint bodies. The tasks of these joint bodies shall be, inter alia, and without prejudice to relevant existing agreements or arrangements, the following:

a. To collect, compile and evaluate data to identify pollution sources likely to cause transboundary impact;

b. to elaborate joint monitoring programmes concerning water quality and quantity;

c. to draw up inventories and exchange information on the pollution sources mentioned in paragraph 2 (a) of this article;

d. to elaborate emission limits for waste water and evaluate the effectiveness of control programmes;

e. to elaborate joint water-quality objectives and criteria having regard to the provisions of article 3 , paragraph 3 of this Convention, and to propose relevant measures for maintaining and, where necessary, improving the existing water quality;

\footnotetext{
27 Available at https://unece.org/fileadmin/DAM/env/water/pdf/water
} con.pdf. f. to develop concerted action programmes for the reduction of pollution loads from both point sources (e.g., municipal and industrial sources) and diffuse sources (particularly from agriculture);

g. to establish warning and alarm procedures;

h. to serve as a forum for the exchange of information on existing and planned uses of water and related installations that are likely to cause transboundary impact;

i. to promote cooperation and exchange of information on the best available technology in accordance with the provisions of article 13 of this Convention, as well as to encourage cooperation in scientific research programmes;

j. to participate in the implementation of environmental impact assessments relating to transboundary waters, in accordance with appropriate international regulations.

3. In cases where a coastal State, being Party to this Convention, is directly and significantly affected by transboundary impact, the Riparian Parties can, if they all so agree, invite that coastal State to be involved in an appropriate manner in the activities of multilateral joint bodies established by Parties riparian to such transboundary waters.

4. Joint bodies according to this Convention shall invite joint bodies, established by coastal States for the protection of the marine environment directly affected by transboundary impact, to cooperate to harmonize their work and to prevent, control and reduce the transboundary impact.

5. Where two or more joint bodies exist in the same catchment area, they shall endeavour to coordinate their activities to strengthen the prevention, control and reduction of transboundary impact within that catchment area".

- 1997 Convention on non-navigational uses of international watercourses (UN watercourses Convention). ${ }^{28}$

Article 8 General obligation to cooperate " 1 . Watercourse States shall cooperate on the basis of sovereign equality, territorial integrity, mutual benefit and good faith to attain optimal utilization and adequate protection of an international watercourse. 2. In determining the manner of such cooperation, watercourse States may consider the establishment of joint mechanisms or commissions, as deemed necessary by them, to facilitate cooperation on relevant measures and procedures in the light of experience gained through cooperation in existing joint mechanisms and commissions in various regions".

\footnotetext{
${ }_{28}$ Available at https://legal.un.org/ilc/texts/instruments/english/conve ntions/8_3_1997.pdf.
} 
- 1998 Albufeira Convention on Cooperation for the Protection and Sustainable Use of Luso-Spanish Watershed Waters $^{29}$

Article 2 Object "The purpose of this Convention is to define the framework for cooperation between the Parties for the protection of surface and groundwater and the aquatic and terrestrial ecosystems directly dependent on them, and for the sustainable use of water resources in the hydrographic basins specified in Article 3, paragraph 1 .

In pursuing this cooperation, the Parties shall observe the rules of this Convention and the applicable principles and rules of international and Community law".

\section{- 2012 UN General Assembly Resolution The future we} want (27 July) (A/RES/66/288) ${ }^{30}$

"15. We reaffirm all the principles of the Rio Declaration on Environment and Development, 3 including, inter alia, the principle of common but differentiated responsibilities, as set out in principle 7 thereof."

58. We affirm that green economy policies in the context of sustainable development and poverty eradication should:

(a) be consistent with international law; (b) respect each country's national sovereignty over their natural resources, taking into account its national circumstances, objectives, responsibilities, priorities and policy space with regard to the three dimensions of sustainable development".

Sustainable development principle and benefit sharing on access to the rivers.

- 1972 UN Stockholm Declaration on Human Development $^{31}$

"Principle 1 Man has the fundamental right to freedom, equality and adequate conditions of life, in an environment of a quality that permits a life of dignity and well-being, and he bears a solemn responsibility to protect and improve the environment for present and future generations. In this respect, policies promoting or perpetuating apartheid, racial segregation, discrimination, colonial and other forms of oppression and foreign domination stand condemned and must be eliminated".
"Principle 2 The natural resources of the earth, including the air, water, land, flora and fauna and especially representative samples of natural ecosystems, must be safeguarded for the benefit of present and future generations through careful planning or management, as appropriate".

- 1992 UN General Assembly Resolution Rio declaration on environment and development (12 August) (A/ CONF.151/26) $)^{32}$

Principle 4 To achieve sustainable development, environmental protection shall constitute an integral part of the development process and cannot be considered in isolation from it.

\section{- 1992 UN Convention on biologic diversity ${ }^{33}$}

"Article 8. In-situ Conservation: Each Contracting Party shall, as faras possible and as appropriate:

(j) subject to its national legislation, respect, preserve and maintain knowledge, innovations and practices of indigenous and local communities embodying traditional lifestyles relevant for the conservation and sustainable use of biological diversity and promote their wider application with the approval and involvement of the holders of such knowledge, innovations and practices and encourage the equitable sharing of the benefits arising from the utilization of such knowledge, innovations and practices"

"Article 15. Access to Genetic Resources: 7. Each Contracting Party shall take legislative, administrative or policy measures, as appropriate, and in accordance with Articles 16 and 19 and, where necessary, through the financial mechanism established by Articles 20 and 21 with the aim of sharing in a fair and equitable way the results of research and development and the benefits arising from the commercial and other utilization of genetic resources with the Contracting Party providing such resources. Such sharing shall be upon mutually agreed terms."

- 1992 UN Water Convention, under General Provisions ${ }^{34}$

\footnotetext{
32 Available at https://www.un.org/en/development/desa/population/ migration/generalassembly/docs/globalcompact/A_CONF.151_26_ Vol.I_Declaration.pdf

33 Available at https://www.cbd.int/doc/legal/cbd-en.pdf

34 Available at https://www.un.org/en/development/desa/population/ migration/generalassembly/docs/globalcompact/A_CONF.151_26_ Vol.I_Declaration.pdf.
} 
"5. In taking the measures referred to in paragraphs 1 and 2 of this article, the Parties shall be guided by the following principles: (...) (c) Water resources shall be managed so that the needs of the present generation are met without compromising the ability of future generations to meet their own needs."

\section{- 1997 UN Watercourses Convention ${ }^{35}$}

"Preamble: Expressing the conviction that a framework convention will ensure the utilization, development, conservation, management and protection of international watercourses and the promotion of the optimal and sustainable utilization thereof for present and future generations"

1998 Albufeira Convention on Cooperation for the Protection and Sustainable Use of Luso-Spanish Watershed Waters ${ }^{36}$

"Article $1 \mathrm{n} .1 \mathrm{e}$ ) "Sustainable use" means one that makes it possible to meet the needs of current generations without compromising the ability of future generations to meet their own needs.

Article 1 Definitions. For the purposes of this Convention, the Parties adopt the following definitions: "Sustainable exploitation" means one that makes it possible to meet the needs of current generations without compromising the ability of future generations to meet their own needs.

Part III Protection and Sustainable Use Article 13 Water quality

1. The Parties, within the Commission, proceed, for each river basin:

(a) to the inventory, assessment and classification of transboundary and other waters susceptible to reciprocal change, depending on their quality status, current and potential uses and interest from the point of view of nature conservation, as well as the definition of quality objectives or standards for these waters, in accordance with the applicable Community directives;

(b) where appropriate, the allocation of special protection status and the definition of special protection objectives for those waters.

2. to achieve the objectives referred to in paragraph 1 , the Parties adopt, when necessary, through the coordination of management plans and measures programs, appropriate actions to:

(a) prevent the degradation of the state of surface water and improve its quality, with a view to achieving its good state, or, in the case of waters with hydrological

\footnotetext{
35 Available at https://unece.org/fileadmin/DAM/env/water/pdf/water con.pdf.

36 Available at https://snirh.apambiente.pt/index.php?idMain=6\& idItem $=1$.
}

regimes modified by human or artificial activity, a good ecological potential;

(b) prevent the degradation of the status of groundwater and improve its quality, with a view to achieving its good condition;

(c) ensure compliance with all water quality standards and objectives classified, according to Community law, as sources for the production of water for human consumption, protection zones for aquatic species of significant economic interest, vulnerable zones, sensitive zones, areas with protection status and recreational areas, including bathing areas.

3. The objectives set out in this provision are carried out in accordance with the terms and deadlines provided for in Community law".

- 2012 UN General Assembly Resolution The future we want (27 July) (A/RES/66/288) $)^{37}$

119. We recognize that water is at the core of sustainable development as it is closely linked to a number of key global challenges. We therefore reiterate the importance of integrating water into sustainable development, and underline the critical importance of water and sanitation within the three dimensions of sustainable development.

\section{High level of protection, no regression and progress principle for the ecologic equilibrium of the rivers}

- 1998 Albufeira Convention on Cooperation for the Protection and Sustainable Use of Luso-Spanish Watershed Waters $^{38}$

"Article 10 Other cooperation measures between the Parties - Actions or measures implementing this Convention may not result in a lower level of protection for the current status of transboundary waters, except in situations and conditions established by Community law".

"Article 13 on Water quality 2. "In order to achieve the objectives referred to in paragraph 1 , the Parties adopt, when necessary, through the coordination of management plans and measures programs, appropriate actions to:

\footnotetext{
37 Available at https://www.un.org/en/development/desa/population/ migration/generalassembly/docs/globalcompact/A_RES_66_288.pdf.

38 Available at https://snirh.apambiente.pt/index.php?idMain=6\& idItem $=1$.
} 
a) prevent the degradation of the state of surface water and improve its quality, with a view to achieving its good state, or, in the case of waters with hydrological regimes modified by human or artificial activity, a good ecological potential;

b) prevent the degradation of the status of groundwater and improve its quality, with a view to achieving its good condition".

- 2000 Charter of Fundamental Rights of the European Union $^{39}$

"Article 37 Environmental protection

A high level of environmental protection and the improvement of the quality of the environment must be integrated into the policies of the Union and ensured in accordance with the principle of sustainable development".

- 2009 Treaty on the Functioning of the European Union Union $^{40}$

"Article 11 - Environmental protection requirements must be integrated into the definition and implementation of the Union's policies and activities, in particular with a view to promoting sustainable development".

\section{- 2015 Paris Agreement on Climate Change ${ }^{41}$}

"Article 4 n. 3. Each Party's successive nationally determined contribution will represent a progression beyond the Party's then current nationally determined contribution and reflect its highest possible ambition, reflecting its common but differentiated responsibilities and respective capabilities, in the light of different national circumstances".

- 2018 Escazu Regional Agreement on Access to Information, Public Participation and Justice in Environmental Matters in Latin America and the Caribbean ${ }^{42}$

"Article 3 Principles: Each Party shall be guided by the following principles in implementing the present Agreement: (c) principle of non-regression and principle of progressive realization"

\footnotetext{
$\overline{39}$ Available at https://www.europarl.europa.eu/charter/pdf/text_en. pdf.

40 Available at https://eur-lex.europa.eu/legal-content/EN/TXT/?uri= celex\%3A12012E\%2FTXT.

41 Available at https://unfccc.int/sites/default/files/english_paris_ agreement.pdf.

42 Available at https://repositorio.cepal.org/bitstream/handle/11362/ 43583/1/S1800428_en.pdf.
}

4. Prevention and precautionary principle and correction at the source for risk management

- 1972 UN Stockholm declaration on human environment $^{43}$

Principle 21 States have, in accordance with the Charter of the United Nations and the principles of international law, the sovereign right to exploit their own resources pursuant to their own environmental policies, and the responsibility to ensure that activities within their jurisdiction or control do not cause damage to the environment of other States or of areas beyond the limits of national jurisdiction.

- 1992 Rio declaration on environment and development ${ }^{44}$

Principle 15 - In order to protect the environment, the precautionary approach shall be widely applied by States according to their capabilities. Where there are threats of serious or irreversible damage, lack of full scientific certainty shall not be used as a reason for postponing costeffective measures to prevent environmental degradation.

- 1992 UN Water Convention, under General Provisions ${ }^{45}$

" 5 . In taking the measures referred to in paragraphs 1 and 2 of this article, the Parties shall be guided by the following principles: (a) the precautionary principle, by virtue of which action to avoid the potential transboundary impact of the release of hazardous substances shall not be postponed on the ground that scientific research has not fully proved a causal link between those substances, on the one hand, and the potential transboundary impact, on the other hand; (b) the polluter-pays principle, by virtue of which costs of pollution prevention, control and reduction measures shall be borne by the polluter."

- 1992 UN Convention on Biodiversity ${ }^{46}$

\footnotetext{
43 Available at https://www.are.admin.ch/are/en/home/sustainabledevelopment/international-cooperation/2030agenda/un-_-milestonesin-sustainable-development/1972--un-conference-on-the-human-envir onment--stockholm.html.

44 Available at https://www.un.org/en/development/desa/population/ migration/generalassembly/docs/globalcompact/A_CONF.151_26_ Vol.I_Declaration.pdf.

${ }^{45}$ Available at https://unece.org/fileadmin/DAM/env/water/pdf/water con.pdf.

46 Available at https://www.cbd.int/doc/legal/cbd-en.pdf.
} 
"Article 14. Impact Assessment and Minimizing Adverse Impacts 1. Each Contracting Party, as far as possible and as appropriate, shall : (d) in the case of imminent or grave danger or damage, originating under its jurisdiction or control, to biological diversity within the area under jurisdiction of other States or in areas beyond the limits of national jurisdiction, notify immediately the potentially affected States of such danger or damage, as well as initiate action to prevent or minimize such danger or damage".

\section{- 1992 UN Convention on Climate change ${ }^{47}$}

"Article 3 Principles In their actions to achieve the objective of the Convention and to implement its provisions, the Parties shall be guided, inter alia, by the following:

3. The Parties should take precautionary measures to anticipate, prevent or minimize the causes of climate change and mitigate its adverse effects. Where there are threats of serious or irreversible damage, lack of full scientific certainty should not be used as a reason for postponing such measures, taking into account that policies and measures to deal with climate change should be cost-effective so as to ensure global benefits at the lowest possible cost. To achieve this, such policies and measures should take into account different socio-economic contexts, be comprehensive, cover all relevant sources, sinks and reservoirs of greenhouse gases and adaptation, and comprise all economic sectors. Efforts to address climate change may be carried out cooperatively by interested Parties".

- 2009 Treaty on the Functioning of the European Union ${ }^{48}$

"Article $191 \mathrm{n} .22$. Union policy on the environment shall aim at a high level of protection taking into account the diversity of situations in the various regions of the Union. It shall be based on the precautionary principle and on the principles that preventive action should be taken, that environmental damage should as a priority be rectified at source and that the polluter should pay".

- 1998 Albufeira Convention on Cooperation for the Protection and Sustainable Use of Luso-Spanish Watershed Waters $^{49}$

"Article 8 Consultations on transboundary impacts

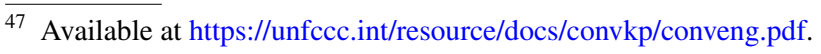

48 Available at https://eur-lex.europa.eu/legal-content/EN/TXT/?uri= celex\%3A12012E\%2FTXT.

49 Available at https://snirh.apambiente.pt/index.php?idMain=6\& idItem $=1$.
}

1. These consultations take place within the Commission, within a period of 6 months, renewable by mutual agreement for the same period, and aim to find a solution that ensures the prevention, elimination, mitigation or control of the impact and, if appropriate, establish the forms of liability in accordance with applicable international and community law, in which case the aforementioned period is renewable twice".

"Article 12 Infrastructure security

The Parties jointly develop specific programs on the safety of hydraulic infrastructures and the assessment of risks that, in the event of a rupture or major accident, could have significant adverse effects on any of the Parties, as well as the assessment of potential risks.

Any such incident is immediately reported to the other Party."

"Article 14 Pollution prevention and control

The Parties coordinate procedures for the prevention and control of pollution caused by topical and diffuse discharges and adopt, within their territory, all measures deemed necessary for the protection of transboundary waters, in accordance with Community law, namely by fixing emission limit values and quality objectives of the receiving environment.

When relevant, the Parties coordinate the necessary measures for the prevention, elimination, mitigation and control of pollution from terrestrial origin of the estuaries and adjacent territorial and marine waters, according to the organizational structure of each State".

- 2018 Escazu Regional Agreement on Access to Information, Public Participation and Justice in Environmental Matters in Latin America and the Caribbean ${ }^{50}$

Article 3 Principles - Each Party shall be guided by the following principles in implementing the present Agreement: (e) Preventive principle; (f) Precautionary principle".

\section{Declarations}

Conflict of interest The author declares that she has no conflict of interest.

\footnotetext{
$\overline{50}$ Available at https://repositorio.cepal.org/bitstream/handle/11362/ 43583/1/S1800428_en.pdf.
} 


\section{References}

Argyrou A, Hummels H (2019) Legal personality and economic livelihood of the Whanganui River: a call for community entrepreneurship. Water Int 44(6-7):752-768. https://doi.org/10.1080/02508 060.2019 .1643525

Bosselmann K (2016) The principle of sustainability transforming law and governance. Routledge, London

Calay R, Dhiman R (2008) An empirical approach to river bed degradation. Int J Multiphys 2:407-419. https://doi.org/10.1260/17509548.2.4.407

de Sadeleer N (2002) Environmental principles, modern and post-modern law. Environmental principles: from political slogans to legal rules. Oxford University Press, Oxford. https://ssrn.com/abstract= 2361955. Accessed 1 July 2021

Di Capua G, Bobrowsky PT, Kieffer SW, Palinkas C (2021) Introduction: geoethics goes beyond the geoscience profession. Geol Soc Lond Spec Publ. https://doi.org/10.1144/SP508-2020-191 ((SP508-2020-191))

Do ÓA, Seiz R (2021) Impacts of climate change in Iberia: less water and more uncertainty in Iberian rivers. ANPIWWF \& WWF España. https://wwfeu.awsassets.panda.org/downloads/impacts_ of_climate_change_in_iberia.pdf. Accessed 1 July 2021

European Commission (2009a) Communication from the Commission on the precautionary principle, COM (2000) 1 final Brussels, 2.2.2000. https://eur-lex.europa.eu/legal-content/EN/TXT/?uri= celex\%3A52000DC0001. Accessed 1 July 2021

European Commission (2009b) Report on Common implementation strategy for the water framework directive (2000/60/EC) Guidance document no. 24, "River basin management in a changing climate". https://circabc.europa.eu/sd/a/a88369ef-df4d-43b18c8c-306ac7c2d6e1/Guidance\%20document\%20n\%2024\%20-\% 20River\%20Basin\%20Management\%20in\%20a\%20Changing\% 20Climate_FINAL.pdf. Accessed 1 July 2021

European Commission (2015) Ecological flows in the implementation of the Water Framework Directive. Guidance document no. 31. https://circabc.europa.eu/sd/a/4063d635-957b-4b6f-bfd4-b51b0 acb2570/Guidance\%20No\%2031\%20-\%20Ecological\%20flows\% 20\%28final\%20version\%29.pdf. Accessed 1 July 2021

European Commission (2016) Notice on access to justice in environmental matters. Communication from the Commission of 28.4.2017(C(2017) 2616 final, Brussels, 28.4.2017. https://ec. europa.eu/environment/aarhus/pdf/notice_accesstojustice.pdf. Accessed 1 July 2021

European Commission (2018) Guidance document on the requirements for hydropower in relation to EU nature legislation (2018/C 213/01). https://eur-lex.europa.eu/legal-content/EN/TXT/PDF/? uri=CELEX:52018XC0618(01)\&from=EN. Accessed 1 July 2021

European Commission (2019) Communication from the Commission to the European Parliament, the Council, the European Economic and Social Committee And the Committee of the Regions (2019) Environmental Implementation Review 2019: a Europe that protects its citizens and enhances their quality of life. https:// ec.europa.eu/environment/eir/pdf/eir_2019.pdf. Accessed 1 July 2021

European Commission (2020a) Improving access to justice in environmental matters in the EU and its Member States. Communication from the Commission to the European Parliament, the Council, the European Economic and Social Committee and the Committee of the Regions, (COM(2020) 643 final Brussels, 14.10.2020. https://ec.europa.eu/environment/aarhus/pdf/communication improving_access_to_justice_environmental_matters.pdf

European Commission (2020b) EU Biodiversity Strategy for 2030 Bringing nature back into our lives, Communication from the
Commission to the European Parliament, the Council, the European Economic and Social Committee and the Committee of the Regions, COM/2020/380 final. https://eur-lex.europa.eu/legalcontent/EN/TXT/?uri=CELEX:52020DC0380

European Environmental Agency (2020) Tracking barriers and their impacts on European river ecosystems. Briefing no. 30/2020 PDFTH-AM-20-030-EN-N-ISBN 978-92-9480-350-4-ISSN 24673196. https://doi.org/10.2800/359938

Falkenmark M, Folke C (2002) The ethics of socio-ecohydrological catchment management: towards hydrosolidarity. Hydrol Earth Syst Sci 6:1-10. https://doi.org/10.5194/hess-6-1-2002

Fedra K (2015) River basin management: what do we really want? Environ Process 2:511-525. https://doi.org/10.1007/ s40710-015-0084-4

Feio MJ, Hughes RM, Callisto M, Nichols SJ, Odume ON, Quintella BR, Kuemmerlen M, Aguiar FC, Almeida SFP, Alonso-EguíaLis $P$ et al (2021) The biological assessment and rehabilitation of the world's rivers: an overview. Water 13:371. https://doi.org/10. 3390/w13030371

Fonseca A, Santos JA, Varandas S, Monteiro S, Martinho JL, Cortes R, Cabecinha E (2020) Current and future ecological status assessment: a new holistic approach for watershed management. Water 12:2839. https://doi.org/10.3390/w12102839

Grases A, Gracia V, Garcia-León M, Lin-Ye J, Sierra JP (2020) Coastal flooding and erosion under a changing climate: implications at a low-lying coast (Ebro Delta). Water 12(2):346. https://doi.org/ 10.3390/w12020346

Gregory KJ, Benito G, Downs PW (2008) Applying fluvial geomorphology to river channel management: background for progress towards a palaeohydrology protocol. Geomorphology 98(12):153-172. https://doi.org/10.1016/j.geomorph.2007.02.031

Groenfeldt D, Schmidt JJ (2013) Ethics and water governance. Global water governance: challenges and future scope. Ecol Soc 18(1):14. https://doi.org/10.5751/ES-04629-180114

Hooper B (2005) Integrated river basin governance. Learning from international experience. IWA Publishing. https://library.oapen. org/handle/20.500.12657/30983. Accessed 1 July 2021

Hull V, Liu J (2018) Telecoupling: a new frontier for global sustainability. Ecol Soc 23(4):41. https://doi.org/10.5751/ES-10494-230441

Jackson S (2010) Compartmentalising culture: the articulation and consideration of Indigenous values in water resource management, Australian Geographer, vol 37, 2006-issue 1: applied naturescultural engagements with Australian environmental management, pp 19-31. https://doi.org/10.1080/00049180500511947

Jager NW, Challies E, Kochskämper E, Newig J, Benson D, Blackstock K, Collins K, Ernst A, Evers M, Feichtinger J, Fritsch O, Gooch G, Grund W, Hedelin B, Hernández-Mora N, Hüesker F, Huitema D, Irvine K, Klinke A, Lange L, Loupsans D, Lubell M, Maganda C, Matczak P, Parés M, Saarikoski H, Slavíková L, Van der Arend S, Von Korff Y (2016) Transforming European water governance? Participation and river basin management under the EU water framework directive in 13 member states. Water 8:156. https://doi.org/10.3390/w8040156

Jans JH, Squintani L, Macrory R, Aragão A, Wegener BW (2009) Gold plating' of European environmental measures? J Eur Environ Plan Law 6(4):417-435

Liu J, Herzberger AJ, Kapsar K, Carlson AK (2019) What Is telecoupling? In: Friis C, Nielsen JØ (eds) Telecoupling, Palgrave studies in natural resource management. Springer Nature. https:// doi.org/10.1007/978-3-030-11105-2_2

Mariachiara A (2018) Environmental principles in maritime and freshwater agreements. Elgar encyclopaedia of environmental law on principles of environmental law. Edward Elgar, pp 525-535 
Marone E, Bohle M (2020) Geoethics for nudging human practices in times of pandemics, preprint, August 2020. https://doi.org/10. 20944/preprints202008.0386.v1

Meister J (2020) Fish protection and guidance at water intakes with horizontal bar rack bypass systems VAW-Mitteilung 258. In: Boes RM (ed) Laboratory of Hydraulics, Hydrology and Glaciology, ETH Zurich, Switzerland. https://www.research-collection.ethz. ch/handle/20.500.11850/455545. Accessed 1 July 2021

Newson MD (1997) Land, water, and development: sustainable management of river basin systems. Routledge, New York. https:// api.taylorfrancis.com/content/books/mono/download?identifier Name $=$ doi\&identifierValue $=10.4324 / 9780203443521 \&$ type $=$ googlepdf

Ojeda AO, Ferrer DB, Mur DM (2006) Cambios en el cauce y el llano de inundación del rio Ebro (Aragón) en los últimos 80 años. https://dialnet.unirioja.es/descarga/articulo/2240543.pdf. Accessed 1 July 2021

Opperman JJ, Shahbol N, Maynard J, Grill G, Higgins J, Tracey D, Thieme M (2021) Safeguarding free-flowing rivers: the global extent of free-flowing rivers in protected areas. Sustainability 13(5):2805

Peppoloni S, Di Capua G, Bilham N (2019) Contemporary geoethics within the geosciences: ethical implications, societal contexts, and professional obligations of the geosciences. Exploring geoethics ethical implications, societal contexts, and professional obligations of the geosciences (Martin Bohle ed.). Palgrave Macmillan, pp 25-70. https://doi.org/10.1007/978-3-030-12010-8_2

Prieur M, Sozzo G (2012) La non régression en droit de l'environnement, Bruylant

Rachid D, Johnny G, Vincent R, Mohamed S, Nicolas R, Bruno T (2015) Microplastic contamination in an urban area: a case study in Greater Paris. Environ Chem 12:592-599. https://doi.org/10. 1071/EN14167
Salman MAS (2021) Equitable and reasonable utilization and the obligation against causing significant harm-are they reconcilable? Interstate disputes over water rights, JIL unbound, vol 115. Cambridge University Press, pp 183-188. https://www.cambridge.org/ core/journals/american-journal-of-international-law/article/equit able-and-reasonable-utilization-and-the-obligation-against-causi ng-significant-harm-are-they-reconcilable/62C01AA29C09D39 7AF23562EE7EDB5F4. Accessed 1 July 2021

Schäfer T (2021) Legal protection schemes for free-flowing rivers in Europe: an overview. Sustainability 13(11):6423

Schmeier S (2021) International water law principles in negotiations and water diplomacy. Interstate disputes over water rights, JIL unbound, vol 115, pp 173-177. https://www.cambridge.org/core/ journals/american-journal-of-international-law/article/internatio nal-water-law-principles-in-negotiations-and-water-diplomacy/ B4B6E3AC4B49A90E974D233DAA9DDFA8. Accessed 1 July 2021

Tignino M (2014) Shared water basins in the European Union. The interaction between European Union law and international law. The interaction between the EU's external environmental policy and international environmental law, Université de Luxembourg

Watters GT (1996) Small dams as barriers to freshwater mussels (Bivalvia, Unionoida) and their hosts. Biol Conserv 75(1):79-85

Whyte KP, Cuomo CJ (2016) Ethics of caring in environmental ethics. In: Gardiner SM, Thompson A (eds) Oxford handbook of environmental ethics. Oxford University Press, Oxford

Publisher's Note Springer Nature remains neutral with regard to jurisdictional claims in published maps and institutional affiliations. 